\title{
Polymorphisms of the glutathione S-transferase P1 gene and head and neck cancer susceptibility
}

Citation for published version (APA):

Oude Ophuis, M. B., Roelofs, H. M., van den Brandt, P. A., Peters, W. H. M., \& Manni, J. J. (2003).

Polymorphisms of the glutathione S-transferase P1 gene and head and neck cancer susceptibility. Head and Neck-Journal for the Sciences and Specialties of the Head and Neck, 25(1), 37-43.

https://doi.org/10.1002/hed.10182

Document status and date:

Published: 01/01/2003

DOI:

10.1002/hed.10182

Document Version:

Publisher's PDF, also known as Version of record

\section{Please check the document version of this publication:}

- A submitted manuscript is the version of the article upon submission and before peer-review. There can be important differences between the submitted version and the official published version of record.

People interested in the research are advised to contact the author for the final version of the publication, or visit the DOI to the publisher's website.

- The final author version and the galley proof are versions of the publication after peer review.

- The final published version features the final layout of the paper including the volume, issue and page numbers.

Link to publication

\footnotetext{
General rights rights.

- You may freely distribute the URL identifying the publication in the public portal. please follow below link for the End User Agreement:

www.umlib.nl/taverne-license

Take down policy

If you believe that this document breaches copyright please contact us at:

repository@maastrichtuniversity.nl

providing details and we will investigate your claim.
}

Copyright and moral rights for the publications made accessible in the public portal are retained by the authors and/or other copyright owners and it is a condition of accessing publications that users recognise and abide by the legal requirements associated with these

- Users may download and print one copy of any publication from the public portal for the purpose of private study or research.

- You may not further distribute the material or use it for any profit-making activity or commercial gain

If the publication is distributed under the terms of Article $25 \mathrm{fa}$ of the Dutch Copyright Act, indicated by the "Taverne" license above, 


\title{
POLYMORPHISMS OF THE GLUTATHIONE S-TRANSFERASE P1 GENE AND HEAD AND NECK CANCER SUSCEPTIBILITY
}

\author{
Michael B. Oude Ophuis, MD, ${ }^{1 *}$ Hennie M. J. Roelofs, MSc, ${ }^{2}$ \\ Piet A. van den Brandt, PhD, ${ }^{3}$ Wilbert H. M. Peters, PhD, ${ }^{2}$ Johannes J. Manni, MD, PhD ${ }^{1}$ \\ ${ }^{1}$ Department of Otorhinolaryngology, Head and Neck Surgery, University Hospital Maastricht, P.O. Box 5800, \\ 6202 AZ Maastricht, The Netherlands. E-mail: Michel@Ophuis.net \\ ${ }^{2}$ Department of Gastroenterology, University Medical Center St. Radboud, Nijmegen, The Netherlands \\ ${ }^{3}$ Department of Epidemiology, Maastricht University, Maastricht, The Netherlands \\ * Present affiliation: Department of Otorhinolaryngology, St. Maartenshospital, Venlo, The Netherlands
}

Accepted 20 May 2002

Published online 4 November 2002 in Wiley InterScience (www.interscience.wiley.com). DOI: 10.1002/hed.10182

\begin{abstract}
Background. Factors determining the individual susceptibility to head and neck squamous cell carcinoma (HNSCC) are still largely unknown. An imbalance between enzymes involved in the toxification and detoxification of (pre)carcinogens closely related to HNSCC, which may appear during smoking and alcohol consumption, may play a role. Genetic polymorphisms in glutathione S-transferases (GSTs) often result in altered detoxification, which may contribute to individual susceptibility to HNSCC.

Methods. We studied the frequencies of polymorphic variants in the GSTP1 gene in 235 patients with HNSCC and 285 healthy controls. In addition, data on exposure to alcohol and tobacco consumption were recorded. DNA was extracted from whole blood, and polymerase chain reaction-based methods were used to detect genetic polymorphisms.

Results. In patients with HNSCC and control groups, the homozygous GSTP1 BB genotype was observed in $12.3 \%$ and $13.6 \%$, respectively. No statistical differences were found for the GSTP1 AA and GSTP1 AB/GSTP1BB genotypes.
\end{abstract}

Correspondence to: M. B. Oude Ophuis

(c) 2002 Wiley Periodicals, Inc.
Conclusions. Our study showed that genetic polymorphisms of GSTP1 are not associated with altered susceptibility to HNSCC. (C) 2002 Wiley Periodicals, Inc. Head Neck 25: 3743, 2003

Keywords: head and neck cancer; glutathione S-transferase P1; phase II enzyme; genetic polymorphism

An imbalance in phase I drug metabolism enzymes, such as cytochromes P450 (CYPs), or phase II detoxification enzymes, such as glutathione S-transferases (GSTs), may contribute to the individual susceptibility to head and neck squamous cell carcinoma (HNSCC). These enzymes, for instance, are involved in the toxification and detoxification of metabolites of polycyclic aromatic hydrocarbons (PAHs), one of the primary carcinogens of tobacco smoke. ${ }^{1}$ Most PAHs first require activation by phase I enzymes to become potential carcinogens that are subsequently detoxified by phase II enzymes. 
As a result of conjugation with glutathione, the potential carcinogens are eliminated, and DNA or other important biomolecules are protected against damage or adduct formation. ${ }^{2-5} \mathrm{In}$ humans, the GST enzymes can be divided into five main classes: Alpha (GSTA), Mu (GSTM), Pi (GSTP), Theta (GSTT), and Zeta (GSTZ). Each class consists of one or more isoenzymes with different, but sometimes overlapping, substrate specificity. ${ }^{4,5}$ At present, genetic polymorphisms have been demonstrated for GSTM1, GSTT1, and GSTP1. ${ }^{5-9}$

Polymorphisms in the GSTP1 gene consist of the variant genotypes $G S T P 1 A B$ and GSTP1 $B B$ next to the wild-type GSTP1 $A A$. The frequency of GSTP1 AA in healthy controls ranges from $42 \%-$ $69 \% .^{9-14}$ A transition of adenine (A) to guanine (G) at nucleotide 313 in exon 5 of the GSTP1 gene results in substitution of isoleucine (Ile) to valine (Val) at position 104 in the amino acid sequence of the protein. ${ }^{7,15,16}$ The valine variants exhibit lower specific activity and affinity for the electrophilic substrates of the enzyme. ${ }^{7,13,15}$ The valinecontaining homozygous variant, GSTP1 $B B$, occurs in approximately $10 \%$ of healthy controls, whereas the heterozygous Ile-Val variant, GSTP1 $A B$, occurs in approximately $35 \%$ of controls. ${ }^{9-14}$

The GSTP1 gene encodes for the isoenzyme GSTP1-1. The GSTP1-1 enzyme level has been extensively studied in relation to tobaccoassociated malignancies. The GSTP1-1 enzyme is overexpressed in many preneoplastic and neoplastic lesions. Elevated tissue levels of GSTP1-1 enzyme have been found in stomach, colorectal, bladder, oral, pharynx, larynx, lung, skin, and breast tumors compared with normal tissues of matched controls. ${ }^{5,17-22}$ The GSTP1-1 enzyme may be involved in the resistance to chemotherapeutic agents and radiotherapy. ${ }^{5,23-25}$ Because GSTP1-1 is also involved in the metabolism and subsequent removal of anticancer drugs, high levels of GSTP1-1 in tumors may contribute to drug resistance in several different cancers. ${ }^{26-28}$ However, there are also contradictory reports.

Because the amino acid changes are the result of the polymorphisms close to the area of hydrophobic binding site for electrophiles, the homozygous GSTP1 $B B$ and heterozygous GSTP1 $A B$ gene products result in a decreased specific activity and affinity for electrophilic compounds. ${ }^{7}$ Thus, the altered metabolic activity of these enzymes could influence susceptibility to head and neck cancer. Earlier we investigated the possible involvement in HNSCC and in benign head and neck lesions of genetic polymorphisms in CYP1A1, GSTM1, and GSTT1, but we found no enhanced rates of GST null genotypes in the cancer population. ${ }^{29}$ Earlier work from our group showed that the GSTP1-1 enzyme, in a quantitative sense, is by far the most important detoxification enzyme in human head and neck tissues. ${ }^{30}$ Therefore, we investigated genetic polymorphisms in GSTP1 in a large series of patients with HNSCC and in matched healthy controls. We also evaluated exposure to alcohol and tobacco of these subjects and evaluated the potential effect modification between GSTP1 polymorphisms and these environmental exposures.

\section{MATERIALS AND METHODS}

Patients and Controls. This case-control study was conducted in the patient referral region of Maastricht University Hospital. A total of 235 Caucasian patients (185 men, 50 women) with primary HNSCC were recruited during their scheduled admission at the Department of Otolaryngology, Head and Neck Surgery of the Maastricht University Hospital between 1994-1998 (mean age 59.1 years; range, 23-86 years). This group consists of 100 patients with laryngeal carcinoma (mean age, 59.9 years; range, 35-85 years), 114 patients with oral cavity/oropharyngeal carcinoma (mean age, 58.0 years; range, 2386 years), and a group of 21 patients (mean age, 61.4 years; range, 41-82 years) with hypopharyngeal carcinoma.

From the same base population, a group of 285 healthy Caucasian blood donors (199 men, 86 women) were recruited at the Blood Transfusion Centre Limburg and served as a control group, frequency matched on age in 10-year age groups (mean age, 50 years; range, 19-91). The investigations were approved by the Medical Ethical Review Committee of the Academic Hospital of the University of Maastricht, and informed consent was obtained from all patients and controls according to the Helsinki Declaration II (1975, revised 1983).

\section{Exposure Assessment, Blood Sampling, and Assess- ment of Genetic Polymorphisms. Information on tobacco use and alcohol consumption was col- lected for all patients and controls by interview. The amount of pack years (PY) was calculated as the number of years smoking $x$ the number of packs a day (assuming 20 cigarettes $=1$ pack). Never smokers were defined as subjects who had smoked less than 1 pack year cumulatively.}


Blood was collected by venapuncture in sterile siliconized EDTA K3 (15\%) 4-mL Vacutainer tubes (Becton Dickinson, San Jose, CA). Immediately after collection, whole blood was stored at $-20^{\circ} \mathrm{C}$ until use. Genomic DNA was isolated from whole blood using the Wizard genomic DNA purification kit, according to the instructions of the manufacturer (Promega, Madison, WI).

Genetic polymorphisms were detected by polymerase chain reaction-restriction fragment length polymorphism (PCR-RFLP). For studying the genetic polymorphism in GSTP1, a primer set (105F and $105 \mathrm{R})$ was designed so that the presence of the A to G substitution at codon 313 resulted in the appearance of an Alw261 restriction enzyme site. ${ }^{9}$ All primers were synthesized by Life Technologies (Breda, The Netherlands). All chemicals needed for PCR were purchased from Promega (Madison, WI).

Statistical Analysis. The statistical program SPSS 8.0 for Windows was used. Information on GSTP1 genotype, smoking, or alcohol was missing in 0,0 , and 11 of the cases and 0,3 , and 1 of controls, respectively. For the purpose of the analysis, the PY of cigarette smoking were categorized as $0,1-20,21-40,41-60$, and $60+\mathrm{PY}$ or in increments of $10 \mathrm{PY}$. Alcohol consumption was categorized as $0-9,10-50$, and $51+\mathrm{g} /$ day. Because there were only three subjects who indicated never to have consumed alcohol, the first category consists of $0-9 \mathrm{~g} / \mathrm{day}$. Analyses were conducted for the total group of patients with HNSCC, as well as for oral cavity/oropharyngeal and laryngeal carcinoma separately. Because of small numbers of hypopharyngeal carcinoma, this group was not evaluated separately.

The association between GSTP1 polymorphisms, smoking, alcohol, and HNSCC was modeled through multivariate logistic regression analysis, controlling for age and gender. First, analyses were conducted to examine the associations between GSTP1 genotype and HNSCC, controlling for age, gender, smoking, and alcohol. Specifically, we evaluated whether subjects with GSTP1 $A A$ are less susceptible to HNSCC than those with GSTP1 $A B / B B$. Likewise associations between smoking and HNSCC or alcohol consumption and HNSCC were examined, controlling for age, gender, and alcohol or smoking, respectively. The strength of the associations was estimated as odds ratios combined with $95 \%$ confidence intervals. Subsequently, logistic regression analyses were performed in which the asso-
Table 1. Frequency distribution of GSTP1 genotypes in HNSCC cases and controls.

\begin{tabular}{|c|c|c|c|c|}
\hline $\begin{array}{l}\text { GSTP1 } \\
\text { genotype }\end{array}$ & $\begin{array}{c}\text { Controls } \\
N(\%)\end{array}$ & $\begin{array}{c}\text { All } \\
\text { HNSCC } \\
\text { cases } \\
N(\%)\end{array}$ & $\begin{array}{c}\text { Oral/oro- } \\
\text { pharynx } \\
N(\%)\end{array}$ & $\begin{array}{l}\text { Larynx } \\
N(\%)\end{array}$ \\
\hline$A A$ & $125(43.9)$ & $116(49.4)$ & $53(46.5)$ & $51(51.0)$ \\
\hline$A B$ & $121(42.5)$ & 90 (38.3) & $48(42.1)$ & $36(36.0)$ \\
\hline$B B$ & 39 (13.6) & 29 (12.3) & $13(11.4)$ & $13(13.0)$ \\
\hline Total & 285 & 235 & 114 & 100 \\
\hline
\end{tabular}

ciation between smoking or alcohol and HNSCC (and its subgroups) was evaluated within subgroups of the GSTP1 genotype, the wild-type GSTP1 AA group, and the combined heterozygote/homozygote GSTP1 $A B / B B$ group. Likelihood ratio tests were conducted to test statistical significance of regression model terms, as well as to test for trends and interactions. Two-sided $p$ values are reported throughout. Finally, the interaction between smoking and alcohol was evaluated, specifically within subgroups of the GSTP1 genotype.

\section{RESULTS}

Table 1 shows the frequency analyses for the A to $\mathrm{G}$ substitution at codon 313 in the GSTP1 gene, which was examined in 235 HNSCC patients and 285 controls. The GSTP1 BB frequency is low in the control group, as well as in the total HNSCC group or its subgroups. To maintain values for appropriate statistical analysis, we combined the frequencies for GSTP1 $A B$ and GSTP1 $B B$ (Tables $3-5)$.In Table 2 , the frequency distribution is given on the smoking habits and the alcohol con-

\begin{tabular}{|c|c|c|c|c|}
\hline Covariable & $\begin{array}{c}\text { Controls } \\
N(\%)\end{array}$ & $\begin{array}{c}\text { All } \\
\text { HNSCC } \\
\text { cases } \\
N(\%)\end{array}$ & $\begin{array}{c}\text { Oral/oro- } \\
\text { pharynx } \\
N(\%)\end{array}$ & $\begin{array}{l}\text { Larynx } \\
N(\%)\end{array}$ \\
\hline \multicolumn{5}{|c|}{ Smoking pack years } \\
\hline 0 & $86(30.2)$ & $13(5.5)$ & $7(6.1)$ & $3(3.0)$ \\
\hline $1-20$ & $130(45.6)$ & 36 (15.3) & $20(17.5)$ & $13(13.0)$ \\
\hline $21-40$ & $60(21.1)$ & $113(48.1)$ & $52(45.6)$ & $53(53.0)$ \\
\hline $41-60+$ & $9(3.2)$ & $73(31.1)$ & 35 (30.7) & $31(31.0)$ \\
\hline Total & 285 & 235 & 114 & 100 \\
\hline \multicolumn{5}{|c|}{ Alcohol g/day } \\
\hline 0-9 & $139(48.8)$ & $18(8.0)$ & 7 (6.3) & $10(10.9)$ \\
\hline $10-50$ & $142(49.8)$ & $106(47.4)$ & $44(39.6)$ & $54(58.7)$ \\
\hline $51+$ & $3(1.1)$ & $100(44.6)$ & $60(54.1)$ & $28(30.4)$ \\
\hline Total & 284 & 224 & 111 & 92 \\
\hline
\end{tabular}




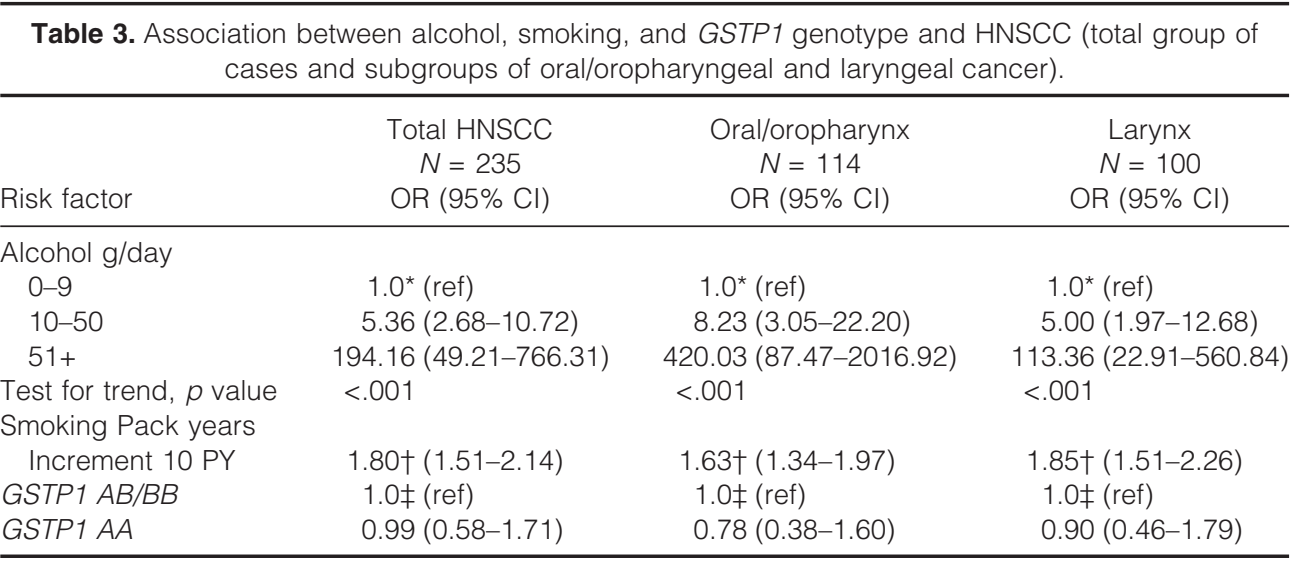

${ }^{*}$ Odds ratio, adjusted for age, gender, smoking, and GSTP1 genotype.

tOdds ratio, adjusted for age, gender, alcohol consumption, and GSTP1 genotype.

$\neq$ Odds ratio, adjusted for age, gender, alcohol consumption, and smoking

Abbreviations: $\mathrm{Cl}$, confidence interval; $\mathrm{OR}$, odds ratio; ref, reference value.

sumption in HNSCC cases, subgroups of HNSCC, and the control group. The HNSCC group in total, as well as the two subgroups, show a significantly higher tobacco exposure compared with the control group. The control group shows significantly lower alcohol consumption than the HNSCC cases (total or subgroups). In the oral/oropharyngeal subgroup, the rate of daily alcohol consumption more than $51 \mathrm{~g} /$ day is much higher compared with the laryngeal subgroup $(54.1 \%$ vs $30.4 \%$, respectively). Alcohol consumption more than 51 g/day hardly exists in the control group.
Table 3 shows that the odds ratios (OR) for alcohol or smoking are similar in the HNSCC group as a total and the two subgroups, except for alcohol consumption more than $51 \mathrm{~g} /$ day, when there is a higher OR in the oral/oropharyngeal group. To provide appropriate statistical values, smoking is displayed with an increment of $10 \mathrm{PY}$. When no adjustment is made for smoking and alcohol (but only for age and gender), the OR for $G S T P 1 A A$ vs $G S T P 1 A B / B B$ will be 1.31 in the total HNSCC group.

The association between alcohol and smoking

\begin{tabular}{|c|c|c|c|}
\hline Risk factor & $\begin{array}{l}\text { Total HNSCC } \\
\text { OR }(95 \% \mathrm{Cl})\end{array}$ & $\begin{array}{l}\text { Oral/oropharynx } \\
\text { OR }(95 \% \mathrm{Cl})\end{array}$ & $\begin{array}{c}\text { Larynx } \\
\text { OR }(95 \% \mathrm{Cl})\end{array}$ \\
\hline \multicolumn{4}{|c|}{$\begin{array}{l}\text { Subgroup GSTP1 AA } \\
\text { (108 cases, } 122 \text { controls) }\end{array}$} \\
\hline \multicolumn{4}{|c|}{ Alcohol g/day } \\
\hline $0-9$ & $1.0^{\star}($ ref $)$ & $1.0^{*}($ ref $)$ & $1.0^{*}($ ref $)$ \\
\hline $10-50$ & $7.89(2.75-22.68)$ & $15.88(2.66-94.66)$ & $6.95(1.76-27.50)$ \\
\hline $51+$ & $232.24(38.22-1407.08)$ & $696.88(70.08-6930.15)$ & $140.16(16.22-1211.12)$ \\
\hline Test for trend, $p$ value & $<.001$ & $<.001$ & $<.001$ \\
\hline \multicolumn{4}{|l|}{ Smoking pack years } \\
\hline Increment $10 \mathrm{PY}$ & $1.51+(1.21-1.80)$ & $1.34+(1.10-1.80)$ & $1.63+(1.21-1.97)$ \\
\hline \multicolumn{4}{|c|}{$\begin{array}{l}\text { Subgroup GSTP1 AB/BB } \\
\text { (116 cases, } 159 \text { controls) }\end{array}$} \\
\hline \multicolumn{4}{|c|}{ Alcohol g/day } \\
\hline $0-9$ & $1.0^{\star}($ ref $)$ & $1.0^{*}($ ref $)$ & $1.0^{*}$ (ref) \\
\hline $10-50$ & $4.21(1.65-10.70)$ & $5.57(1.64-18.89)$ & $3.70(1.07-12.84)$ \\
\hline $51+$ & $191.67(20.88-1759.33)$ & $307.88(26.42-3588.09)$ & $74.82(6.76-828.31)$ \\
\hline Test for trend, $p$ value & $<.001$ & $<.001$ & $<.001$ \\
\hline \multicolumn{4}{|l|}{ Smoking pack years } \\
\hline Increment $10 \mathrm{PY}$ & $2.28+(1.73-3.01)$ & $2.41 \dagger(1.67-3.47)$ & $2.46+(1.74-3.49)$ \\
\hline
\end{tabular}

${ }^{*}$ Adjusted for age, gender, smoking

tAdjusted for age, gender, and alcohol.

Abbreviations: $\mathrm{Cl}$, confidence interval; OR, odds ratio; ref, reference value. 
and the GSTP1 polymorphisms is shown in Table 4. For oral/oropharyngeal cases with the GSTP1 $A A$ genotype, alcohol consumption more than doubles the OR compared with the GSTP1 AB/ $B B$ genotype. This is also shown for laryngeal carcinoma. In the oral/oropharyngeal cases, as well as the laryngeal cases with the GSTP1 $A B / B B$ genotype, odds ratios are increased by smoking compared with the GSTP1 AA genotype. We tested for interaction of alcohol consumption between subgroups of GSTP1 in the total HNSCC group; LR-X $=0.96, d f=2, p>.05$. Also the interaction of smoking between subgroups of GSTP1 in the total HNSCC group is calculated; LR-X $=6.04, d f=1, p<.025$.

In Table 5 we show a significant interaction between smoking and alcohol consumption in HNSCC susceptibility when not adjusted for GSTP1 genotype. The effect of smoking is stronger when more alcohol is consumed (OR increases from 1.27 to 3.53). However, because of small numbers (especially in high alcohol consumption category), interaction between alcohol and smoking and GSTP1 genotype cannot be fully calculated.

\footnotetext{
Table 5. Interaction between alcohol and smoking regarding risk of HNSCC in total group and in subgroups defined by GSTP1 genotype.

\begin{tabular}{lc}
\hline & $\begin{array}{c}\text { Smoking } \\
\text { OR }(95 \% \mathrm{Cl}) \\
\text { per } 10\end{array}$ \\
pack years
\end{tabular}
}

\section{DISCUSSION}

Glutathione S-transferases are involved in the detoxification of a wide variety of chemical carcinogens, including those derived from cigarette smoke. ${ }^{5}$

The enzyme GSTP1-1 is known to catalyze the detoxification of $\mathrm{PAH}$ in vitro and may be a major enzyme involved in the detoxification of tobaccorelated metabolic products in vivo. ${ }^{5}$ The expression in tissues may vary, depending on site or localization, and immunohistochemical studies have shown a constant and widespread GSTP1-1 expression throughout pharyngeal and laryngeal squamous cell epithelium in both normal and tumor tissue. ${ }^{10}$ Earlier we showed that GSTP1-1 is the most important GST enzyme in human head and neck tissues. ${ }^{30}$ Therefore, we studied the occurrence of polymorphisms of this gene in patients with different head and neck tumors and controls.

We previously reported that the GSTM1 and GSTT1 null genotypes are not associated with an increased susceptibility for HNSCC. ${ }^{29}$ In one of the largest studies performed so far, we found no significant association between risk of HNSCC and occurrence of genetic polymorphisms in the GSTP1 gene. This was also found for oral/ oropharyngeal cancers and laryngeal cancers separately.

The GSTP1-1 enzyme is overexpressed in many neoplastic lesions, such as malignancies of stomach, colorectum, bladder, oral tissue, pharynx, larynx, lung, skin, and breast compared with corresponding normal tissues. ${ }^{5,17-22,30}$ However, when estimating GSTP1-1 serum levels in patients with head and neck cancer, we found significantly higher levels compared with controls, but no association with GSTP1 genotype was observed. ${ }^{31}$ This may strongly indicate that the overexpression of GSTP1-1 in head and neck cancer is not dependent on genotype but most probably transcriptionally regulated.

We found a strong association between smoking and alcohol consumption and HNSCC susceptibility. Assessment of smoking or alcohol consumption is difficult, especially with respect to patient history for the total accumulative exposure. Exposure usually takes place over many years and is not always consistent. In addition, different cigarette brands may yield completely different nicotine and tar exposures. High consumption of alcohol often is not revealed by patients because of its social unacceptance. It there- 
fore would help to determine biomarkers such as serum gamma-glutamyltransferase, which could be indicative of recent consumption of alcohol. Development of biomarkers that could indicate the exposure and the period of consumption would be more helpful.

In our control population, GSTP1 BB occurs in $13.6 \%$ and GSTP1 $A B$ in $42.5 \%$. Our data for the healthy controls are in agreement with the genotype frequencies in the control populations reported by other researchers.9-14 Similar observations were found for the HNSCC group (12.3\% and $38.3 \%$, respectively).

Our data for HNSCC patients are also in agreement with several other studies performed. Lin et $\mathrm{al}^{14}$ found that polymorphisms in GSTP1 were not associated with increased risk for esophageal cancer. They even found a slightly lower occurrence of GSTP1 $A B$ or $B B$ genotypes in cancer and hyperplasia cases than in controls. ${ }^{14}$ Jourenkova-Mironova et $\mathrm{al}^{32}$ and Matthias et $\mathrm{al}^{10}$ found no association between the GSTP1 $A B$ or $B B$ genotypes and risk of larynx cancer. Harries et $\mathrm{al}^{9}$ reported an association between the occurrence of the GSTP1 polymorphism and susceptibility to bladder or testicular cancer but found no association with breast or colon cancer. In other studies, no association was found between the GSTP1 polymorphism and colorectal, lung, or breast cancer. ${ }^{33,34}$

Several other studies, however, revealed a significant correlation between occurrence of GSTP1 polymorphisms and preneoplastic and neoplastic lesions. Lung cancer patients had a significant higher frequency of GSTP1 BB genotype (15.9\%) and a lower frequency of GSTP1 AA genotype (38.4\%) than controls $(9.1 \%$ and $51.5 \%$, respectively). ${ }^{12}$ Homozygous GSTP1 BB was found significantly more often in patients with Barrett's esophagus and esophageal adenocarcinoma. ${ }^{35}$ Matthias et $\mathrm{al}^{10}$ reported that GSTP1 polymorphism influences susceptibility to pharyngeal but not to laryngeal squamous cell carcinoma. However, when comparing our patient groups in a similar way as Matthias et $\mathrm{al}^{10}$ (oral cavity/ oropharyngeal SCC and hypopharyngeal SCC versus laryngeal SCC), we did not find a significant difference in the genotype distributions. Ryberg et $\mathrm{al}^{12}$ reported that patients with the GSTP1 BB genotype had higher DNA adduct levels in lung tissue than the GSTP1 AA genotypes. They also found a linear trend between DNA adduct levels and occurrence rates of GSTP1 B alleles.
The variant genotypes GSTP1 $A B$ and GSTP1 $B B$ showed a different specific activity and affinity for several electrophilic substrates but were identical in their affinity for glutathione. ${ }^{7,15}$ The properties of the variant genotypes were conducted in "in vitro experiments" with recombinant proteins by Ali Osman et al, ${ }^{7}$ which, however, does not necessarily provide adequate information on the enzymes and their reactions "in vivo." In agreement with the in vitro results, Watson et $\mathrm{al}^{13}$ and van Lieshout et $\mathrm{al}^{35}$ reported a significantly lower conjugating activity with 1-chloro-2,4-dinitrobenzene (CDNB) in lung and esophageal tissue samples, respectively, in patients with GSTP1 $A B$ and GSTP1 BB compared with GSTP1 AA genotypes.

In summary, we found no evidence for a possible genetic predisposition to HNSCC because of genetic polymorphisms in the GSTP1 gene. This suggests that the carcinogens involved in the etiology of HNSCC may not be critically dependent on detoxification by GSTP1-1. Further studies on other combinations of polymorphic genotypes in detoxification enzymes and their relation to local and systemic enzyme concentration seem to be justified.

\section{REFERENCES}

1. Pelkonen O, Nebert DW. Metabolism of polycyclic aromatic hydrocarbons: etiologic role in carcinogenesis. Pharmacol Rev 1982;34:189-222.

2. Mannervik B, Danielson UH. Glutathione transferasesstructure and catalytic activity. CRC Crit Rev Biochem 1988;23:283-337.

3. Board P, Coggan M, Johnston P, Ross V, Suzuki T, Webb G. Genetic heterogeneity of the human glutathione transferases: a complex of gene families. Pharmacol Ther 1990; 48:357-369.

4. Beckett GJ, Hayes JD. Glutathione S-transferases: biomedical applications. Adv Clin Chem 1993;30:281-380.

5. Hayes JD, Pulford DJ. The glutathione S-transferase supergene family: regulation of GST and the contribution of the isoenzymes to cancer chemoprotection and drug resistance. Crit Rev Biochem Mol Biol 1995;30:445-600.

6. Ahmad H, Wilson DE, Fritz RR, et al. Primary and secondary structural analyses of glutathione S-transferase pi from human placenta. Arch Biochem Biophys 1990;278: 398-408.

7. Ali-Osman F, Akande O, Antoun G, Mao JX, Buolamwini J. Molecular cloning, characterization, and expression in Escherichia coli of full-length cDNAs of three human glutathione S-transferase Pi gene variants. Evidence for differential catalytic activity of the encoded proteins. J Biol Chem 1997;272:10004-100012.

8. Pemble S, Schroeder KR, Spencer SR, et al. Human glutathione S-transferase theta (GSTT1): cDNA cloning and the characterization of a genetic polymorphism. Biochem J 1994;300:271-276.

9. Harries LW, Stubbins MJ, Forman D, Howard GC, Wolf CR. Identification of genetic polymorphisms at the glutathione S- transferase Pi locus and association with sus- 
ceptibility to bladder, testicular and prostate cancer. Carcinogenesis 1997;18:641-644.

10. Matthias C, Bockmühl U, Jahnke V, et al. The glutathione S-transferase GSTP1 polymorphism: effects on susceptibility to oral/pharyngeal and laryngeal carcinomas. Pharmacogenetics 1998;8:1-6.

11. Morita S, Yano M, Tsujinaka T, et al. Genetic polymorphisms of drug-metabolizing enzymes and susceptibility to head-and-neck squamous-cell carcinoma. Int J Cancer 1999;80:685-688.

12. Ryberg D, Skaug V, Hewer A, et al. Genotypes of glutathione transferase M1 and P1 and their significance for lung DNA adduct levels and cancer risk. Carcinogenesis 1997;18:1285-1289.

13. Watson MA, Stewart RK, Smith GB, Massey TE, Bell DA. Human glutathione S-transferase P1 polymorphisms: relationship to lung tissue enzyme activity and population frequency distribution. Carcinogenesis 1998;19:275-280.

14. Lin DX, Tang YM, Peng Q, Lu SX, Ambrosone CB, Kadlubar FF. Susceptibility to esophageal cancer and genetic polymorphisms in glutathione S-transferases T1, P1, and M1 and cytochrome P450 2E1. Cancer Epidemiol Biomarkers Prev 1998;7:1013-1018.

15. Zimniak P, Nanduri B, Pikula S, et al. Naturally occurring human glutathione S-transferase GSTP1-1 isoforms with isoleucine and valine in position 104 differ in enzymic properties. Eur J Biochem 1994;224:893-899.

16. Hu X, O’Donnell R, Srivastava SK, et al. Active site architecture of polymorphic forms of human glutathione $\mathrm{S}$ transferase P1-1 accounts for their enantioselectivity and disparate activity in the glutathione conjugation of 7beta,8alpha-dihydroxy- 9alpha,10alpha-ox y-7,8,9,10tetrahydrobenzo(a)pyrene. Biochem Biophys Res Commun 1997;235:424-428.

17. Peters WHM, Boon CE, Roelofs HMJ, Wobbes T, Nagengast FM, Kremers PG. Expression of drug-metabolizing enzymes and P-170 glycoprotein in colorectal carcinoma and normal mucosa. Gastroenterology 192;103:448-455.

18. Katagiri A, Tomita Y, Nishiyama T, Kimura M, Sato S. Immunohistochemical detection of P-glycoprotein and GSTP1-1 in testis cancer. Br J Cancer 1993;68:125-129.

19. Tsuchida S, Sekine Y, Shineha R, Nishihira T, Sato K. Elevation of the placental glutathione S-transferase form (GST-pi) in tumor tissues and the levels in sera of patients with cancer. Cancer Res 1989;49:5225-5229.

20. Niitsu Y, Takahashi Y, Saito T, et al. Serum glutathioneS-transferase-pi as a tumor marker for gastrointestinal malignancies. Cancer 1989;63:317-323.

21. Hirata S, Odajima T, Kohama G, Ishigaki S, Niitsu Y. Significance of glutathione S-transferase-pi as a tumor marker in patients with oral cancer. Cancer 1992;70: 2381-2387.

22. Tanita J, Tsuchida S, Hozawa J, Sato K. Expression of glutathione S-transferase-pi in human squamous cell carcinomas of the pharynx and larynx. Loss after radiation therapy. Cancer 1993;72:569-576.
23. Armstrong DK, Gordon GB, Hilton J, Streeper RT, Colvin OM, Davidson NE. Hepsulfam sensitivity in human breast cancer cell lines: the role of glutathione and glutathione S-transferase in resistance. Cancer Res 1992;52: 1416-1421.

24. Awasthi S, Sharma R, Singhal SS, Herzog NK, Chaubey M, Awasthi YC. Modulation of cisplatin cytotoxicity by sulphasalazine. Br J Cancer 1994;70:190-194.

25. Cheng X, Kigawa J, Minagawa Y, et al. Glutathione Stransferase-pi expression and glutathione concentration in ovarian carcinoma before and after chemotherapy. Cancer 1997;79:521-527.

26. Gilbert L, Elwood LJ, Merino M, et al. A pilot study of pi-class glutathione S-transferase expression in breast cancer: correlation with estrogen receptor expression and prognosis in node-negative breast cancer. J Clin Oncol 1993;11:49-58.

27. Gaffey MJ, Iezzoni JC, Meredith SD, et al. Cyclin D1 (PRAD1, CCND1) and glutathione-S-transferase pi gene expression in head and neck squamous cell carcinoma. Hum Pathol 1995;26:1221-1226.

28. Russo D, Marie JP, Zhou DC, et al. Coexpression of anionic glutathione-S-transferase (GST pi) and multidrug resistance (mdr1) genes in acute myeloid and lymphoid leukemias. Leukemia 1994;8:881-884.

29. Oude Ophuis MB, van Lieshout EMM, Roelofs HMJ, Peters WHM, Manni JJ. Glutathione S-transferase M1 and $\mathrm{T} 1$ and cytochrome $\mathrm{P} 4501 \mathrm{~A} 1$ polymorphisms in relation to the risk for benign and malignant head and neck lesions. Cancer 1998;82:936-943.

30. Mulder TPJ, Manni JJ, Roelofs HMJ, Peters WHM, Wiersma A. Glutathione S-transferases and glutathione in human head and neck cancer. Carcinogenesis 1995;16: 619-624.

31. Kelders WPA, Oude Ophuis MB, Roelofs HMJ, Peters WHM, Manni JJ. The association between glutathione S-transferase P1 genotype and plasma level in head and neck cancer. Laryngoscope 2002;112:462-467.

32. Jourenkova-Mironova N, Voho A, Bouchardy C, et al. Glutathione S-transferase GSTM3 and GSTP1 genotypes and larynx cancer risk. Cancer Epidemiol Biomarkers Prev 1999;8:185-188.

33. Harris MJ, Coggan M, Langton L, Wilson SR, Board PG. Polymorphism of the Pi class glutathione S-transferase in normal populations and cancer patients. Pharmacogenetics 1998;8:27-31.

34. Helzlsouer KJ, Selmin O, Huang HY, et al. Association between glutathione S-transferase M1, P1, and T1 genetic polymorphisms and development of breast cancer. J Natl Cancer Inst 1998;90:512-518.

35. van Lieshout EMM, Roelofs HMJ, Dekker S. Polymorphic expression of the glutathione S-transferase P1 gene and its susceptibility to Barrett's esophagus and esophageal carcinoma. Cancer Res 1999;59:586-589. 